\title{
Practice corner: Sleepless in Sydney-is valerian an effective alternative to benzodiazepines in the treatment of insomnia?
}

$\mathrm{T}$ his practice corner considers a clinical question that arose at the author's outreach clinic at a soup kitchen in urban Sydney. It highlights some of the practical issues that affect the equitable application of evidence with disadvantaged patients.

\section{THE PROBLEM}

Jason dropped by the clinic looking fidgety and agitated. He is 32 years old with a history of substance abuse that includes paint sniffing and narcotic abuse. On a previous visit, he told me that he injects crushed and filtered morphine tablets twice a week "to relax," and I suspect that he has harmed himself in the past.

He sleeps "rough" in parks, railway stations, and squats and presented to the clinic asking for something to help him sleep. He says it is "noisy" on the streets and he hasn't had a decent night's sleep for a long time, yet he refuses to access emergency shelter accommodation. I'm very reluctant to prescribe him benzodiazepines but sympathise with his sleeping problems. So I wondered about the effectiveness of the herbal root extract, valerian, as an alternative treatment for insomnia and went looking for the best available evidence.

\section{SEARCHING AND APPRAISAL}

My usual approach to searching is to look first in the Cochrane Library for systematic reviews and trials in the controlled trials register and then to search Medline via PubMed Clinical Queries (www.ncbi.nlm.nih.gov/entrez/query/static/clinical. html). No relevant systematic reviews were found in the Cochrane Library, but 1 was found in Medline. ${ }^{1}$ However, this review was a few years old, and I had noted that a more recent randomised controlled trial had appeared in the Cochrane Controlled Trials Register. A further search with the "treatment" filter on PubMed Clinical Queries for trials from 1999 onwards found 3 more recent trials among people with mild insomnia. ${ }^{2-4}$ After only a few minutes of searching, I had a full text copy of a systematic review plus abstracts for 3 additional randomised trials that appeared to address my question. Like many clinicians, I could only access copies of the abstracts for the 3 trials in Medline, which hampered my ability to do a full critical appraisal. One abstract reported that they used a double blind, placebo controlled method, and 2 used a crossover design, so allocation concealment and blinding were likely. It is unclear whether a washout period was used in the crossover trials. One trial compared 2 different valerian extracts with each other and not against placebo or any other treatment comparison; the method of randomisation could not be determined from the abstract, so I decided to exclude it at this stage. ${ }^{4}$

The methods section of the systematic review ${ }^{1}$ provided only limited information, but the Jadad criteria ${ }^{5}$ were used to rate the quality of the 9 included trials and the review was not limited to English publications. These 9 trials fell into 2 broad groups -6 trials of relatively poor quality (scores $=1-$ 2 ) and 3 trials of fairly high quality ( score $=5$ ).
I decided to consider the results of the 3 higher quality trials from the systematic review ${ }^{26-8}$ and the 2 more recent trials I had located on Medline ${ }^{2}{ }^{3}$ rather than accept the conclusion of the systematic review that the evidence for valerian as a treatment for insomnia is inconclusive. The table shows the brief summary I compiled.

Four of the trials reported better effectiveness of valerian compared with placebo for improving sleep quality, and 1 trial suggested that the effects might be comparable to oxazepam. The only effect size I could find in the information I had to hand was in the Vorbach et al paper, ${ }^{6}$ which states that $66 \%$ patients on valerian reported improved sleep compared with $26 \%$ on placebo. Given that my patient is "sleeping rough," I expect that the effect could be less in his case. Provided that a maximum dose of 450-600 mg valerian nightly is maintained over consecutive nights, it appears that adverse events are mild but may be fairly common $(28 \%$ patients in the study by Ziegler et $a l^{2}$ ). Adverse events were more common with oxazepam and even with placebo in 1 trial. One trial's duration was 6 weeks, but drug dependency was not reported in the abstract.

\section{APPLICATION}

It appears from the best available evidence that valerian extract may be an effective treatment for mild insomnia compared with placebo and could have similar effects to those of oxazepam on sleep quality. Short term use of valerian 450-600 mg nightly for 1 or 2 weeks is a reasonable option to discuss with Jason. The discussion section of the systematic review $^{1}$ notes a lack of evidence about the long term effects of valerian and some case reports of hepatotoxicity, cardiac complications, and central nervous system effects upon valerian withdrawal, particularly at higher doses. The risks of benzodiazepine overdose are much higher in his case.

Given Jason's social circumstances and history of substance abuse, valerian would be a reasonable treatment option for his insomnia. However, one of the most significant barriers to applying this evidence is cost. In practice, because Jason is dependent on welfare, he is entitled to subsidised prescription medication under the Australian healthcare system. A bottle of benzodiazepine tablets, subsidised on prescription, would cost him around $\$ \mathrm{~A} 3.50$ but a bottle of valerian tablets, which are not a prescription item, would cost approximately \$A20. The charity that operates our soup kitchen will subsidise this cost for Jason, but it does raise questions about equity in the application of evidence amongst disadvantaged patients.

\section{REFLECTIONS ON THE PROCESS}

I could have done several things differently in answering this clinical question. A referee suggested I could have searched other secondary sources of summarised evidence before PubMed Clinical Queries. Had I taken the time to go to Bandolier, I would have found an article about the Stevinson 
Summary of best available evidence on the effectiveness of valerian for insomnia

\begin{tabular}{|c|c|c|c|c|c|c|}
\hline Study & $\begin{array}{l}\text { Sample } \\
\text { (N) }\end{array}$ & Design & Intervention & Comparison & n Outcome & Adverse events \\
\hline $\begin{array}{l}\text { Leathwood ef al } \\
(1982)^{7}\end{array}$ & 8 & $\begin{array}{l}\text { Crossover trial, } \\
4 \text { nights of } \\
\text { each treatment in } \\
\text { random order. }\end{array}$ & $\begin{array}{l}450 \mathrm{mg} \text { or } 900 \mathrm{mg} \\
\text { aqueous valerian } \\
\text { extract. }\end{array}$ & Placebo & $\begin{array}{l}\text { Valerian at both doses significantly } \\
\text { reduced sleep latency and quality in early } \\
\text { part of the night measured by movement } \\
\text { wrist meters compared with placebo. } \\
\text { (Effect size not reported in systematic } \\
\text { review. No abstract available on Medline) }\end{array}$ & $\begin{array}{l}900 \mathrm{mg} \text { valerian resulted in } \\
\text { greater sleepiness in the } \\
\text { morning. }\end{array}$ \\
\hline $\begin{array}{l}\text { Leathwood \& } \\
\text { Chauffard (1985) }\end{array}$ & 128 & $\begin{array}{l}\text { Crossover trial, } \\
3 \text { nights of each } \\
\text { treatment in } \\
\text { random order. }\end{array}$ & $\begin{array}{l}400 \mathrm{mg} \text { aqueous } \\
\text { valerian or combined } \\
60 \mathrm{mg} \text { valerian } / 30 \\
\mathrm{mg} \text { hops. }\end{array}$ & Placebo & $\begin{array}{l}\text { Valerian improves sleep latency and } \\
\text { quality compared with placebo. } \\
\text { (Effect sizes not reported in systematic } \\
\text { review. No abstract available on Medline.) }\end{array}$ & $\begin{array}{l}\text { Nausea in } 1 \text { patient (group } \\
\text { uncertain). Morning } \\
\text { sleepiness greater in } \\
\text { combined valerian/hops } \\
\text { group. }\end{array}$ \\
\hline $\begin{array}{l}\text { Vorbach etal } \\
(1996)^{6}\end{array}$ & 121 & $\begin{array}{l}\text { Multicentre, } \\
\text { placebo controlled } \\
\text { trial. }\end{array}$ & $\begin{array}{l}600 \mathrm{mg} \text { ethanol } \\
\text { valerian extract } \\
\text { (LI 156) for } 28 \text { days. }\end{array}$ & Placebo & $\begin{array}{l}4 \text { validated rating scales. Valerian better } \\
\text { than placebo on clinical global impression } \\
\text { scale after } 14 \text { days. } 66 \% \text { rated valerian } \\
\text { effective compared with } 26 \% \text { placebo. }\end{array}$ & $\begin{array}{l}2 \text { patients on valerian } \\
\text { reported headache and } \\
\text { feeling dazed in the } \\
\text { morning. Placebo effects not } \\
\text { reported. }\end{array}$ \\
\hline $\begin{array}{l}\text { Donath et al } \\
(2000)^{3}\end{array}$ & 16 & $\begin{array}{l}\text { Randomised, } \\
\text { double blind, } \\
\text { placebo controlled, } \\
\text { crossover trial. }\end{array}$ & $\begin{array}{l}\text { Radix valerianae } \\
\text { (dose not reported } \\
\text { in abstract). }\end{array}$ & Placebo & $\begin{array}{l}\text { Polysomnographic (PSG) recordings. } \\
\text { After multiple doses, slow wave sleep } \\
\text { latency reduced with valerian } v \text { placebo } \\
(21.3 v 13.5 \text { min, } p<0.05) \text { Slow wave } \\
\text { percentage time also increased with } \\
\text { valerian compared with placebo }(9.8 \% v \\
8.1 \% \text {, } p<0.05) \text {. Subjective sleep quality } \\
\text { correlated with these results. }\end{array}$ & $\begin{array}{l}\text { Low adverse events in } \\
\text { valerian group compared } \\
\text { with placebo }(3 \vee 18) \text {. }\end{array}$ \\
\hline $\begin{array}{l}\text { Ziegler et al } \\
(2002)^{2}\end{array}$ & 202 & $\begin{array}{l}\text { Multicentre, } \\
\text { randomised, } \\
\text { double blind trial. }\end{array}$ & $\begin{array}{l}600 \mathrm{mg} \text { valerian } \\
\text { LI } 156 \text { for } 6 \\
\text { weeks }\end{array}$ & $\begin{array}{l}10 \mathrm{mg} \\
\text { oxazepam }\end{array}$ & $\begin{array}{l}\text { Similar effects on sleep quality and sleep } \\
\text { questionnaire (refreshment after sleep, } \\
\text { evening psychic stability, psychosomatic } \\
\text { symptoms, dream recall, sleep duration). }\end{array}$ & $\begin{array}{l}28 \% \text { valerian } \vee 36 \% \\
\text { oxazepam. Mild only. }\end{array}$ \\
\hline
\end{tabular}

review, ${ }^{9}$ which provided an expert's interpretation of the efficacy of valerian and I may have chosen to take it at face value. However, I would still want to know about any primary studies published after 2000 and available on Medline. Guideline clearing houses (http://www.guidelines.gov) and meta-search engines (http://sumsearch.uthscsa.edu/) are other options. But for the busy clinician there is a trade off between the time to search secondary sources and the likelihood of finding additional evidence. Although the increasing number of secondary sources of evidence is very welcome, the quality and the currency of these sources always need to be appraised. This still requires time and skill. The recency of the review and the likelihood of subsequently published trials are ways of gauging whether you should search further. The Cochrane Controlled Trials Register can alert you to recent trials while you search for systematic reviews.

I have deliberately chosen to write about this case as I think it illustrates some of the challenges that clinicians and their patients face when applying the best available evidence in practice. Firstly, the evidence for the effectiveness of valerian is not as complete as one would like. The generalisability of particular preparations and dosages used in the trials are not directly comparable to those available in my practice. Of greater concern is the lack of available evidence about the potential harms and benefits of longer term use.

Evidence-based clinical decisions often combine a complex blend of evidence, practitioner and patient preferences, clinical findings, and contextual factors. ${ }^{10}$ If I were to consider a balance sheet of treatment options for Jason, it might include the following considerations:

- Option I-Jason and I could agree to do nothing about his insomnia. The benefit of this option would be the avoidance of treatment side effects, but the harms may be that his sleep remains problematic and he is very likely to self medicate with injectable narcotics.

- Option 2-Jason could use emergency shelters periodically. The benefit of this option might be that shelter staff may be able to help him toward longer term accommodation options and treatment of his addictions. A potential problem with this option in many cities is the difficulty of accessing shelter accommodation, particularly for men with addictions. Shelters are often poorly funded and crowded, and some men feel unsafe in dormitory settings where assaults and theft unfortunately do occur. Many of my patients have experienced this and often prefer to remain "on the streets." This will of course vary greatly from city to city but may be a consideration in Jason's case.

- Option 3-Jason and I could agree to a trial of valerian for 4-5 nights at a time. This option might improve his sleep and reduce the likelihood of him self medicating with injectable narcotics. If he only has 4-5 tablets provided at a time, the risks of overdose, dependence, abuse, or selling the tablets is reduced. The need for regular visits to the clinic to monitor this might provide an opportunity to discuss his broader health and social problems. The potential risks of this approach are that he may still inject narcotics and "top up" with valerian. We have found no evidence regarding interaction of valerian with other drugs. The cost of valerian is also somewhat problematic in Jason's case, and the use of limited charitable resources for this purpose needs to be carefully weighed.

My brief literature review informs option 3-if there had been no sound evidence of efficacy, option 3 could have been eliminated. With some evidence of efficacy, option 3 may prove preferable to Jason and provide an inroad to dealing with his difficult problems. 
LYNDAL TREVENA, MBBS(Hons), MPhilPH University of Sydney School of Public Health Sydney, New South Wales, Australia

1 Stevinson C. Ernst E. Valerian for insomnia: a systematic review of randomized clinical trials. Sleep Med 2000;1:91-99.

2 Ziegler G, Ploch M, Miettinen-Baumann A, et al. Efficacy and tolerability of valerian extract $\mathrm{LI} 156$ compared with ozazepam in the treatment of nonorganic insomnia-a randomized, double-blind, comparative clinical study. Eur J Med Res 2002;7:480-6.

3 Donath F, Quispe S, Diefenbach K, et al. Critical evaluation of the effect of valerian extract on sleep structure and sleep quality. Pharmacopsychiatry 2000;33:47-53.

4 Herrera-Arellano $A$, Luna-Villegas $G$, Cuevas-Uriostegui $M$, et al. Polysomnographic evaluation of the hypnotic effect of Valeriana edulis standardized extract in patients suffering from insomnia. Planta Med 2001;67:695-9.
5 Jadad AR, Moore RA, Carrol D, et al. Assessing the quality of reports of randomised clinical trials: is blinding necessary? Control Clin Trials 1996;17:1-12.

6 Vorbach EU, Gortelmeyer R, Bruning J. Therapie von Insomnien: Wirksamkeit und Vertraglichkeit eines Baldrianpraparats. Psychopharmakotherapie 1996;3:109-115

7 Leathwood PD, Chauffard F, Heck E, et al. Aqueous extract of valerian rooth (Valeria officinalis L.) improves sleep quality in man. Pharmacol Biochem Behav 1982;17:65-71.

8 Leathwood PD, Chauffard F. Aqueous extract of valerian reduces latency to fall asleep in man. Planta Med 1985 Apr;(2): 144-148.

9 Valerian for insomnia. Bandolier Journal 2000:81-7. hitp:// www.jr2.ox.ac.uk/bandolier/band81/b81-7.html

10 Haynes R, Devereaux P, Guyatt G. Clinical expertise in the era of evidence-based medicine and patient choice. Evidence-Based Medicine 2002;7:36-38

\section{EBM notebook}

\section{Campaign to revitalise academic medicine}

A group of medical journals led by the BMJ are undertaking to help identify opportunities and address the problems of academic medicine. Peter Tugwell, a rheumatologist, clinical epidemiologist, and former chair of medicine at the University of Ottawa, is coordinating the project, which will "bring people together to debate whether the existing structure of academic medicine is still fundamentally sound and, if not, to propose alternatives to it."
Views from all quarters-doctors, patients, other stakeholders, and the public-are avidly sought, along with nominations of self or others to engage in the process. Thus, all readers are invited to read the inaugural editorial ${ }^{1}$ and interact with the campaign's new website (http:// bmj.bmjjournals.com/academicmedicine/).

THE EDITORS

1 Tugwell P. Campaign to revitalise academic medicine kicks off. We need a deep and broad international debate to begin. (editorial). BMJ 2004;328 597. http://bmi.bmijournals.com/cgi/content/full/328/7440/597 